\title{
GENERALIZATIONS AND REFINEMENTS OF STEČKIN-TYPE INEQUALITY FOR TANGENT AND SECANT FUNCTIONS
}

\author{
Chao-Ping Chen and Neven Elezović
}

Abstract. In this paper, we generalize and refine Stečkin-type inequality for the tangent function. We develop an inequality of Chen and Sándor for the secant function to produce a general form. We also present some refinements of the inequality for the secant function.

Mathematics subject classification (2010): 26 D05.

Keywords and phrases: Trigonometric function, inequalities.

\section{REFERENCES}

[1] M. Abramowitz and I. A. Stegun (Editors), Handbook of Mathematical Functions with Formulas, Graphs, and Mathematical Tables, National Bureau of Standards, Dover, New York, 1965.

[2] H. AlzER, Sharp bounds for the Bernoulli numbers, Arch. Math. 74 (2000), 207-211.

[3] G. D. Anderson, S. - L. Qiu, M. K. Vamanamurthy and M. Vuorinen, Generalized elliptic integral and modular equations, Pacific J. Math. 192 (2000), 1-37.

[4] G. D. Anderson, M. K. Vamanamurthy and M. Vuorinen, Conformal Invariants, Inequalities, and Quasiconformal Maps, New York, 1997.

[5] G. D. Anderson, M. K. VAMAnAmurthy AND M. VuORINEN, Monotonicity of Some Functions in Calculus, available at http://www . math. auckland.ac.nz/Research/Reports/Series/538.pdf.

[6] D. S. Mitrinović, Analytic Inequalities, Springer, New York, 1970.

[7] B. BAnjac, M. MAKRAGić AND B. MALEŠEviĆ, Some notes on a method for proving inequalities by computer, Results. Math. 69, 1 (2016), 161-176.

[8] M. BECKER AND E. L. STARK, On a hierarchy of quolynomial inequalities for tan $x$, Univ. Beograd. Publ. Elektrotehn. Fak. Ser. Mat. Fiz. No. 602-633 (1978), 133-138.

[9] C. - P. Chen And W. - S. Cheung, Sharp Cusa and Becker-Stark inequalities, J. Inequal. Appl. 2011 (2011) 136, http://www . journalof inequalitiesandapplications . com/content/2011/1/136.

[10] C. - P. Chen And N. Elezović, Sharp Redheffer-type and Becker-Stark-type inequalities with an application, Math. Inequal. Appl. 21, 4 (2018), 1059-1078.

[11] C. - P. CHEN AND R. B. PARIS, Series representations of the remainders in the expansions for certain trigonometric functions and some related inequalities, I, Math. Inequal. Appl. 20, 4 (2017), 10031016.

[12] C. - P. CHEN AND J. SÁNDOR, Sharp inequalities for trigonometric and hyperbolic functions, J. Math. Inequal. 9, 1 (2015), 203-217.

[13] L. Debnath, C. Mortici And L. Zhu, Refinements of Jordan-Stečkin and Becker-Stark inequalities, Results Math. 67 (2015), 207-215.

[14] H. - F. GE, New Sharp Bounds for the Bernoulli Numbers and Refinement of Becker-Stark Inequalities, J. Inequal. Appl. 2012, Article ID 137507, 7 pages.

[15] I. S. GRAdShteyn, I. M. RYZHIK, Table of integrals, series, and products, translated from the Russian, sixth edition, translation edited and with a preface by Alan Jeffrey and Daniel Zwillinger, Academic Press, Inc., San Diego, CA, 2000. 
[16] Y. NishizaWA, Sharp Becker-Stark's type inequalities with power exponential functions, J. Inequal. Appl. 2015 (2015) 402,

http://rd.springer.com/article/10.1186/s13660-015-0932-9/fulltext.html.

[17] Y. Nishizawa, Sharp exponential approximate inequalities for trigonometric functions, Results Math. 71 (2017), 609-621.

[18] S. B. STEČKIn, Some remarks on trigonometric polynomials, Uspekhi Matematicheskikh Nauk, vol. 10, no. 1 (63), (1955) 159-166 (in Russian).

[19] Z. - J. SUn AND L. ZHU, Simple proofs of the Cusa-Huygens-type and Becker-Stark-type inequalities, J. Math. Inequal. 7 (2013), 563-567.

[20] L. ZHU, Sharp Becker-Stark-type inequalities for Bessel functions, J. Inequal. Appl. 2010, Article ID 838740,4 pages.

[21] L. ZHU, A refinement of the Becker-Stark inequalities, Math. Notes 93 (2013), 421-425.

[22] L. Zhu AND J. K. HUA, Sharpening the Becker-Stark inequalities, J. Inequal. Appl. 2010, Article ID 931275, 4 pages. 